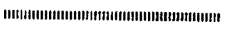 \\ 論 文 \\ UDC $669.162 .16: 662.749 .2: 669.162 .263 .4: 546.31: 669.88$ ними \\ アルカリ吸着によるコークスの劣化についで
}

\author{
張東 植**. 館充***

\section{Degradation of Coke due to Alkali Adsorption} \\ Tongshik GHANG and Mitsuru TATE
}

\begin{abstract}
Synopsis:
A fundamental study on the degradation by alkali adsorption of two cokes made from ordinary (A) and specially inferior (B) coal blends, which had been used in the 26th run of the experimental blast furnace, was carried out.

Following results were obtained:

1) The rate of alkali adsorption at the temperature ranging from 800 to $1000^{\circ} \mathrm{G}$ in $\mathrm{N}_{2}$ atmosphere depends on the initial porosity of coke.

2) Alkali is adsorbed by either coke and its rate near $1 \%$ of enough to generate macro-cracks. The degree of macro-crack formation increases with the increase of alkali adsorption, and it is higher in the less porous coke (A) than in the more porous one (B) under the same rate of alkali adsorption.

3) The presence of $\mathrm{CO}_{2}$ in the atmosphere diminishes macro-cracks due to alkali adsorption, and the crack formation is completely prevented at some $P_{\mathrm{CO}_{2}}$ higher than $0.05 \sim 0.06 \mathrm{~atm}$.

4) Micro-strengths of every macro-cracked cokes and of coke fines generated by alkali adsorption decrease extremely.

Alkali adsorption is considered to be a cause of degradation common to all kinds of coke, but it is difficult to regard it as the cause of remarkable degradation of coke (B) in the 26th run.
\end{abstract}

\section{1. 緒言}

高炉装入物中のアルカリは炬内を循環しながら蓄積さ れ, 高さ方向にアルカリ含量最大部のある分布を形成す ることが, 解体調查結果から知られている1)

アルカリの循環・蓄積は, 炉下部高温域においてアル カリおよびアルカリ化合物がガス相へ移行し，このガス が炉内を上昇し，上部低温域で装入物に吸収され，また は凝縮することによつて，再び炉内を下降するというサ イクルを繰返しておこる．この循環フルカリの主成分は K(カリウム) であり,その存在形態はシアン化物である といら報告がある5).

最近の高炉解体調查結果によつて炉内でのコークスの 劣化状況が知られ，それがアルカリ分布状態とよく対応 していることから, 劣化の一つの要因として, アルカリ 存在下でのガス化反応による劣化，すなわちアルカリの 触媒作用による急激なソリュション・ロス反応が，コー クス基質の脆弱化をもたらすと考兄られている. 一方,
他の要因として, アルカリがュークスに吸着されたたけ でき裂が発生してュークスの細粒化が起ることが考えら れる. 後者の劣化要因の根拠は, 東京大学生産技術研究 所の試験高炉第 $25 \cdot 26$ 次操業における劣質コークス使 用時の, 吹卸し後炉内残留コークスの諸調査結果46) か ら推測されたもので, アルカリ吸着によつてコークスに マク口的・ミクロ的き裂が発生し, これが細粒化を招い たものと推察された.

本報では，とくにアルカリ吸着に焦点をしぼり，これ によるコークスの劣化を実験室的に確認し, さらにはそ の結果を第 $25 \cdot 26$ 次操業の炉内残留コークスの諸調査 結果4)6) と対応させることにより, 細粒化要因を検討し た.

\section{2. 実験装置および実験条件}

\section{$2 \cdot 1$ 実験装置および方法}

本研究を進めるに当たつて, 試験目的に応じて 4 段階 7) 10)の実験を行なつた.

* 昭和 50 年 10 月, 51 年 10 月, 52 年 10 月本会講演大会にて発表 昭和 53 年 6 月 15 日受付 (Received June 15, 1978)

** 東京大学生産技術研究所 (Institute of Industrial Science, The University of Tokyo, 1-8 Yayoi-cho Chiba 280)

*** 東京大学生産技術研究所工博 (Institute of Industrial Science, The University of Tokyo) 
第 1 段階と第 2 段階ではコークスへのアルカリ吸着条 件をみつけることを，第 3 段階と第 4 段階ではアルカリ のコークス劣化に及ぽす定量的なデータを得ることを主 眼とした.

実験装置は各段階すべて異なつており，第 1 段階7)11) では横型ェレマ炉を使用した。なお，第 2 段階8)，第 3 段階9)さらに第 4 段階10)で使用した装置を，それぞれ Fig. 1, Fig. 2 さらに Fig. 3 に示した.

第 2 段階の装置（Fig. 1) はタンマン炉を使用し，コ ークスとアルカリ充填部は黒鉛るつぼを使用した。 アル カリ充填部は炉の中心部にくるようにセットし、コーク スはその上部の低温領域部に装入した。 アルカリはニッ ケルるつぼに入れ，磁器製の受台にのせ，黒鉛るつぼと 接触しないよう工夫した。 なお，アルカリは突沸を防ぐ ためあらかじめ溶融冷却した。

ユークスとアルカリは常温から炉内にセットし，炉内 に $\mathrm{N}_{2}$ ガスを微量流しながら加熱し，アルカリ部が沸点 温度に到達してから，所定量のキァリァーガスを流し， アルカリ蒸気をコークス層に流入させるようにした。

第 3 段階の装置（Fig. 2) は, 長四角形の構造を有 し，発熱部は上，下に二分されている．上部にはコーク ス試料を，下部にはアルカリを装入し，それぞれ任意の 温度にコントロールできるようになつている．炉芯管は 21/2インチの SGPを，反応管は 2 インチのステンレス 製管を使用した。

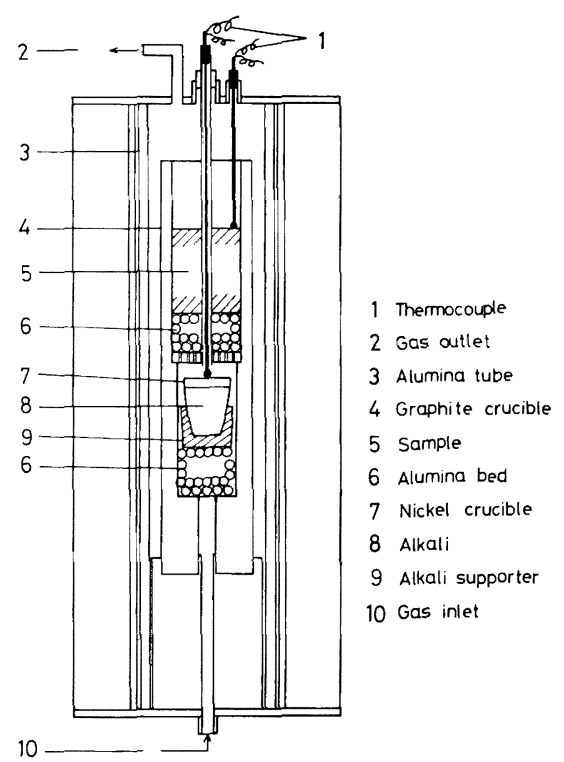

Fig. 1. Schematic diagram of experimental apparatus used in the 2 nd stage.
アルカリはニッケルるつぼに入れ，アルカリ挿入装置 にセットして持く、コークス試料を入れた反応管を上部 発熱部にセットし，上部から $\mathrm{N}_{2}$ ガスを微量流しながら

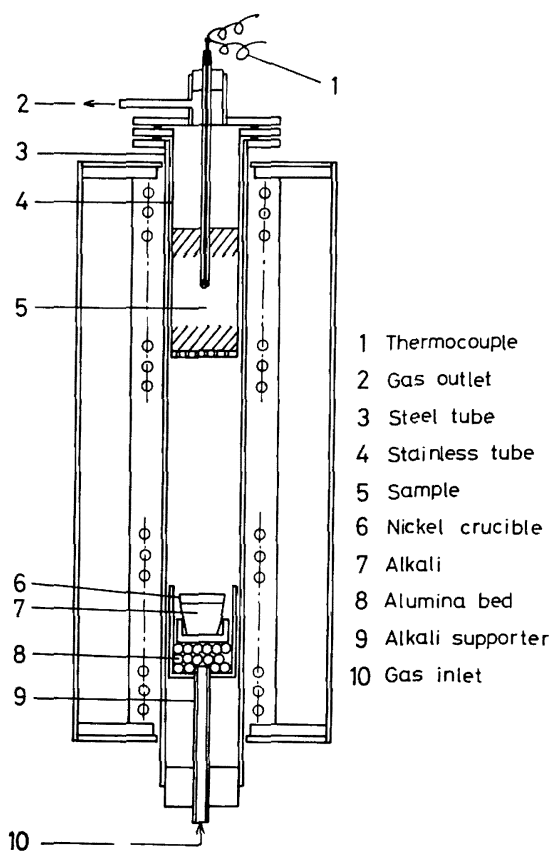

Fig. 2. Schematic diagram of experimental apparatus used in the $3 \mathrm{rd}$ stage.

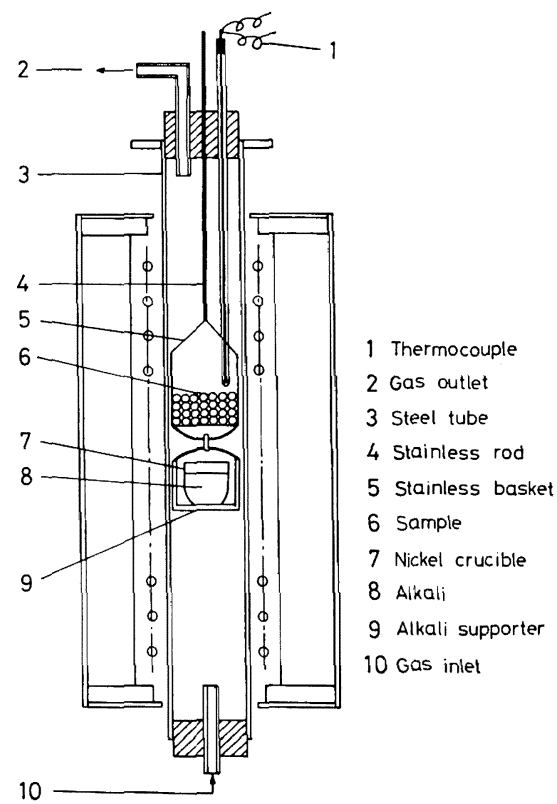

Fig. 3. Schematic diagram of experimental apparatus used in the 4 th stage. 
Table 1. Experimental conditions.

\begin{tabular}{c|c|c|c|c|c|c|c|c}
\hline Stage & $\begin{array}{c}\text { Goke size } \\
(\mathrm{mm})\end{array}$ & $\begin{array}{c}\text { Sample weight } \\
(\mathrm{g})\end{array}$ & $\begin{array}{c}\text { Alkali weight } \\
(\mathrm{g})\end{array}$ & $\begin{array}{c}\text { Alkali temper- } \\
\text { ature }\left({ }^{\circ} \mathrm{G}\right)\end{array}$ & $\begin{array}{c}\text { Coke temper- } \\
\text { ature }\left({ }^{\circ} \mathrm{G}\right)\end{array}$ & $\begin{array}{c}\text { Atmosphere } \\
(\mathrm{l} / \mathrm{min})\end{array}$ & $\begin{array}{c}\text { Reaction time } \\
(\mathrm{h})\end{array}$ \\
\hline 1 & $9.52 \sim 12.7$ & 100 & $\begin{array}{c}\mathrm{KGl}: 10 \\
\mathrm{NaCl}: 10\end{array}$ & 800 & 1000 & $\mathrm{~N}_{3}(100 \%), 4$ & $0.5 \sim 1.5$ \\
\hline 2 & $20 \sim 25$ & 100 & $\mathrm{KOH}: 35$ & $1320 \sim 1350$ & $950 \sim 1250$ & $\mathrm{~N}_{2}(100 \%), 4$ & $1 \sim 2$ \\
\hline 3 & $9.52 \sim 12.7$ & 150 & $\mathrm{KOH}: 70$ & 1100 & $730 \sim 800$ & $\mathrm{~N}_{2}(100 \%), 4$ & $<2$ \\
\hline 4 & $9.52 \sim 12.7$ & 25 & $\mathrm{KOH}: 50$ & $800,900,1000$ & $\begin{array}{l}\mathrm{N}_{2}(100 \%), 4 \\
\frac{\mathrm{N}_{2}+\mathrm{CO}_{2}\left(\mathrm{CO}_{2}\right.}{=1 \sim 6 \%), 4}\end{array}$ & 1 \\
\hline
\end{tabular}

上，下部の発熱部を昇温する. 系内が所定の温度に到達 後, アルカリ挿入装置を下部からゆつくりと挿入し所定 の位置にセットする. アルカリ充媜部が再び所定温度に 到達してから，ガスの流れを切り換え，下部から所定量 のキャリアーガスを流し，アルカリ蒸気をコークス層内 に流入させた。

第 4 段階 (Fig. 3) の実験ではコークス試料を $55 \mathrm{~mm} \phi$ のステンレス製カゴに装入して，眓の位置にセットし， アルカリはニッケルるつぼに入れ試料の面下 $40 \mathrm{~mm}$ の位 㯰にるつぼ受血によつて吊した。

炉内に $\mathrm{N}_{2}$ ガスを微量流しながら加熱し，系内が所定 の温度に到達後，フルカリを吊した試料を上部よりゆつ くりと挿入し所定位置にセットする.コークス充填部が 再び所定の温度に到達してから, 所定量のキャリアーガ スを流し，アルカリ蒸気をュークス層内に流入させた.

所定時間アルカリ流入後, 試料を上部よりとり出し, アルカリ吸着率とき裂発生率を測定した。な拉，アルカ リ吸着による劣化程度は, き裂発生率とマイクロ・スト レングス指数（以下これを MSI と記す）で評価した.

\section{$2 \cdot 2$ 実験条件}

Table 1 に各段階の実験条件を一括して示した。な お，害験に供した試料は，第 1 段階と第 2 段階では第 52 次操業で使用したB (贫質) コークスを，第 3 段階と 第 4 段階では第 26 次操業の $\mathrm{A}$ (良質), $\mathrm{B}$ (劣質)ニーク スを使用した.

第 1 段階では，まずアルカリ種として $\mathrm{KCl}, \mathrm{NaCl}$ を 採用したが、コークスに全くき裂の発生が認められなか つた.

この原因として, アルカリ種の不適切さ，装置上の制 約からアルカリ部温度が $800^{\circ} \mathrm{C}$ までしか昇温できず, 気化フルカリ分王が低いことが考えられた。

第 2 段階では, アルカリ種として $\mathrm{KOH}$ を採用し, そ の沸点 (1 320 1350 $\mathrm{C})$ まで加熱してアルカリ分圧を 高めることにより，コークスへのマクロき裂（コークス
粒子の表面から内部に入る肉眼観察で確認できる）の発 生と，このき裂に起因した細粒化コークス（2～5 mm大 に破砕されたコークス粒子）が確認された。

そこでコークス部温度とアルカリ分圧を変化させた 時のアルカリ吸着率とき裂発生率との関係を求め, この 関係からき裂発生のコークス温度とアルカリ分圧との対 応関係を明らかにすることを目的として，第 3 段階の実 験を行なつた。この段階でも Table l に示した実験条 件でのみ，確かにマクロき裂と細粒化コークスの発生が 確認された。しかし，この段階で使用した装置 (Fig. 2) はアルカリ部とコークス部の中間部に低温領域が生じ, この部分の炬芯管壁にアルカリが吸着され, その吸着量 が各実験ごとに変化するため, 結局コークス部への流通 するアルカリ分玨のコントロールができなかつた.

このよらにコークス部とアルカリ揮発部温度をとれぞ れ任意に可変とし, しかもアルカリ分王を一定にコント ロールすることには装置上かなりの困難があるので，第 4 段階ではアルカリを一定の 分王で流すことたけを考 え, アルカリソースをコークス部の直下に括き, 両者の 温度を同一にしてこの問題を回避した.

第 4 段階では，とくに試料量を $25 \mathrm{~g}$ と極力減らして 高さ方向のアルカリ吸着率の分布をさけるよらにした. また本実験で用いたコークスの化学的成分を Table 2 に示した.

本実験に先だ, Table 1 の第 4 段階の温度 800,900 , $1000^{\circ} \mathrm{C}$ におけるアルカリ分圧の再現性試験を試み, こ の結果を Fig.4 に示した. な持，ここにいらアルカリ 分压： $P_{\mathrm{K}}$ は, アルカリ $(\mathrm{KOH})$ の蒸発速度を一定とみ なしてアルカリの重量減からK(カリウム)に換算して算 出したみかけの値である.

この図から明らかなよらにアルカリ分圧は温度上昇に 伴つて高くなるが, 同一条件下でのアルカリ分区の再現 珄は覀く, ど温度についても測定値にバラッキがみら れる.しかし，そのハラッッキを考慮しても平均的なアル 
Table 2. Chemical analysis of tested coke.

\begin{tabular}{c|c|c|c|c|c|c|c|c|c}
\hline \multirow{2}{*}{$\begin{array}{c}\text { Components } \\
\text { Kinds of Coke }\end{array}$} & F. C & V. $\mathrm{M}$ & $\mathrm{Ash}$ & $\mathrm{SiO}_{2}$ & $\mathrm{Fe}_{2} \mathrm{O}_{3}$ & $\mathrm{Al}_{2} \mathrm{O}_{3}$ & $\mathrm{CaO}$ & $\mathrm{Na}$ & $\mathrm{K}$ \\
\hline Coke B* & 83.80 & 1.80 & 14.40 & 54.85 & 6.59 & 27.53 & 2.45 & 0.6 & 2.02 \\
\hline Goke A** & 86.58 & 0.98 & 12.44 & 49.18 & 12.94 & 32.13 & 2.49 & 0.39 & 1.24 \\
\hline Coke B** & 86.38 & 1.03 & 12.58 & 49.55 & 13.31 & 32.52 & 2.94 & 0.38 & 1.33 \\
\hline
\end{tabular}

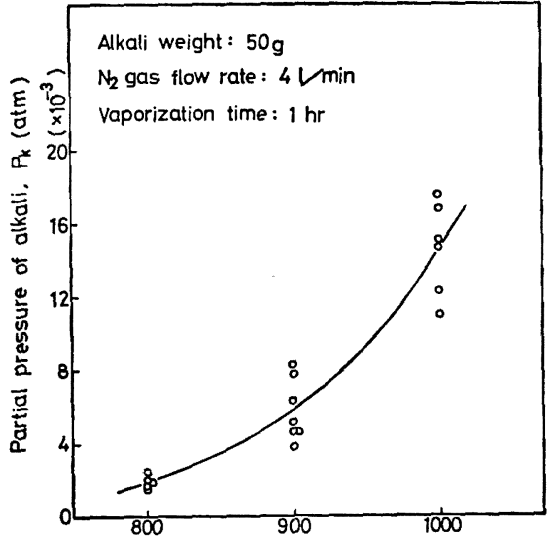

Vaporization temperature of alkali $\left({ }^{\circ} \mathrm{C}\right)$

Fig. 4. Relation between vaporization temperatute of alkali and partial pressure of alkali.

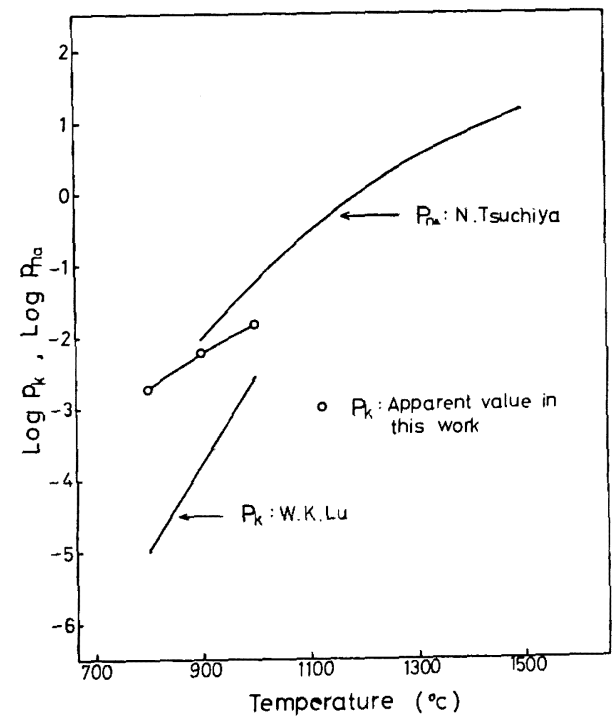

Fig. 5. Partial pressure of alkali at various temperature.

カリ分圧 (Fig. 4 の実線部) は温度依存性があること

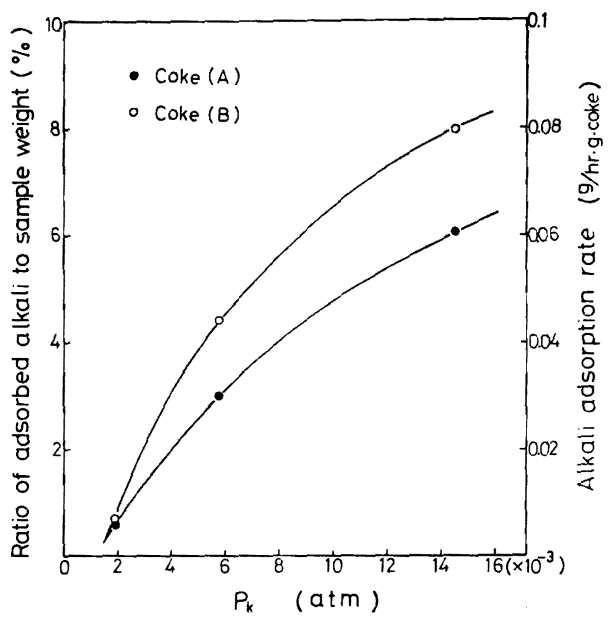

Fig. 6. Relation between $P_{\mathrm{K}}$ and alkali adsorption ratio, alkali adsorption rate.

がわかる、またこのアルカリ分圧のバラッキの結果と して，当然コークスへのアルカリ吸着率ならびにき裂発 生率にもバラッキがみられた。したがつて，本実験では 同一条件で少なくとも数点の実験を行ない，得られたデ 一タを平均して代表値とした。

また，現在までのところ高炉下部に特けるアルカリ分

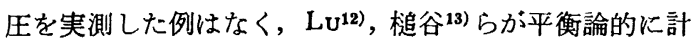
算した例があるだけである。そこでこれらを Fig． 5 に 本実験条件でのアルカリ分王とともにプロットして対比 した.この図によると本条件でのアルカリ分王は Lu, 桘谷らの平衡値の中間にあたつている．たたし実際には コークス側にアルカリが吸着されるので，分圧はさらに 若干低下するはずである.

\section{3. 実験結果および考察}

本報では，アルカリ吸着速度，アルカリ吸着率とき裂 発生率との関係などについては第 4 段階の実験データ, アルカリを吸着した試料の顕微鏡所見は第 2 段階の試 料またアルカリを吸着した試料の EPMA，X 線回折 および強度特性などについては第 3 段階の試料について 

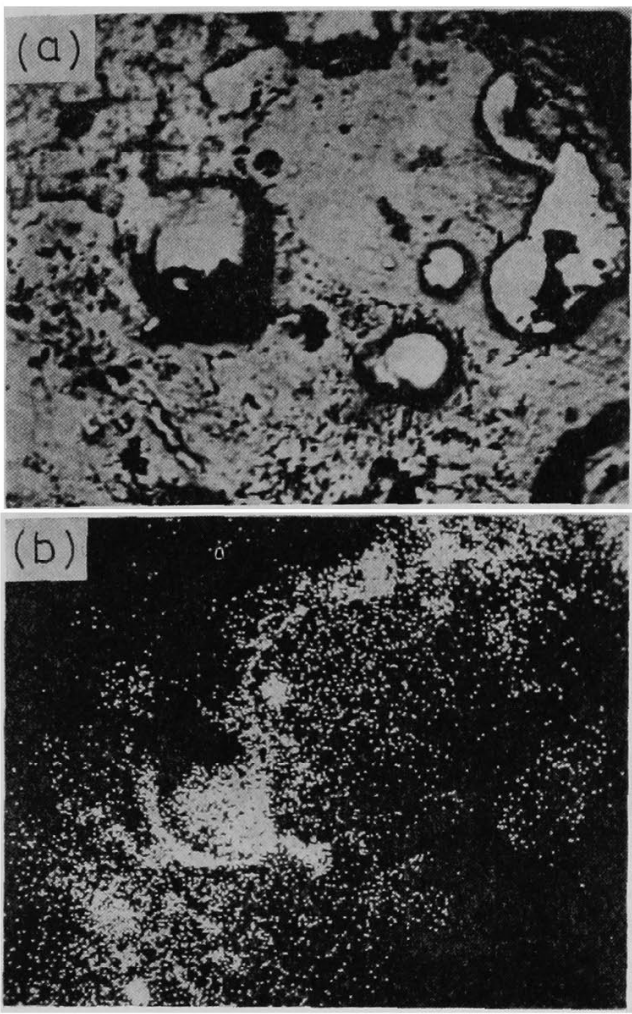

(a) Secondany electron

(b) $\mathrm{K}$

Photo. 1. X-ray image (by EPMA) of coke after adsorption of alkali by $1.93 \mathrm{wt} \%(\times 250)$.

述ペる.

\section{1 アルカリ吸着速度について}

Fig. 6 にアルカリ吸着率扰よびアルカリ吸着速度のア ルカリ分圧依存性を示した. ここにアルカリ吸着率と は，コークス試料の実験前後の重量差の実験前重量に対 する割合を意味する。また，アルカリ吸着速度は一定と みなして, 単位時間, 単位重量あたりについて示した.

この図から明らかなよらにアルカリ吸着率および吸着 速度はアルカリ分压に依存し, アルカリ分王の增大に伴 つて増大するのがわかる，また両者はコークス種によつ て異なり，Bコークスの方が大き，かつアルカリ分圧 の増大に伴つてAュークスとの差が大きくなつている.

この吸着アルカリがュークス粒内のどの位置に分布す るかを EPMA 観察によつて調べた結果を Photo. 1 に 示した.

Photo. 1 はBコークスのアルカリ吸着率が $1.93 \%$ の 場合の分布を示したもので，これからアルカリは気孔内 壁部に多量に存在し，との周辺のカーボン質内部へと侵 入することがわかる.このことはアルカリ吸着率（吸着
速度）がコークス気孔率に依存すること，またアルカリ は当初気孔内壁部に吸着され，そこからカーボン質内部 へと抬散していくことを示唆している.

事実，気孔率はBコークスが $47.7 \%$ で，Aュークス では $45.1 \%$ と前者の方が大きくなつて拈り，この気孔 率のちがいが Fig. 6 で示されるアルカリ吸着率（吸着 速度）の差を生じたものと思われる. またこの結果は近 藤14) らの報告とも一致する.

\section{2 アルカリ吸着によるコークスの劣化状況}

ここでは，アルカリ吸着によるコークスの劣化状況を き裂発生率で評価し，アルカリ吸着率之の関係，き裂発 生率の $P_{\mathrm{CO}_{2}}$ 依存性, さらにアルカリ吸着によつて劣化 したコークスの強度特性などについて調査した。

$3 \cdot 2 \cdot 1$ アルカリ吸着率とマクロき裂扣よび細粒化ュ 一クス発生率について

コークスがアルカリをある量吸着すると， マクロき裂 と細粒化コークスが発生することがわかつた.

このマクロき裂を生じたコークスを実験後の全コーク ス粒子から肉眼観察にもとついて選び出し，その実験前 重量に対する比をマクロき裂発生率と定義してこれを求 め，同様にして細粒化コークス発生率（第 3 段階におけ る試料について）を求め, これらとアルカリ吸着率との 関係を Fig. 7 に示した.これからA，Bコークスはい ずれもアルカリ吸着率の增大に伴つて, マクロき裂発生 率と細粒化コークスの発生率が増大し, しかもアルカリ

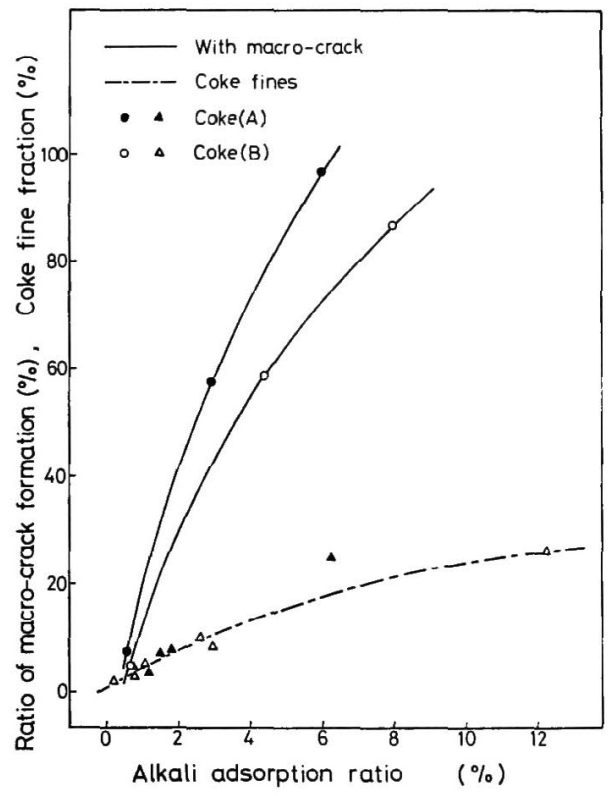

Fig. 7. Dependence of macro-crack formation, coke fine fraction on alkali adsorption. 

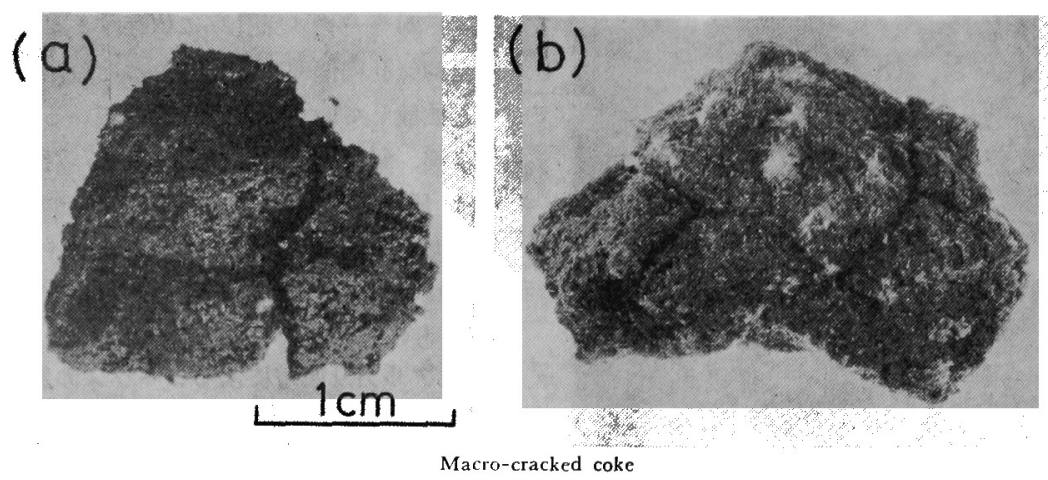

\section{( á)}
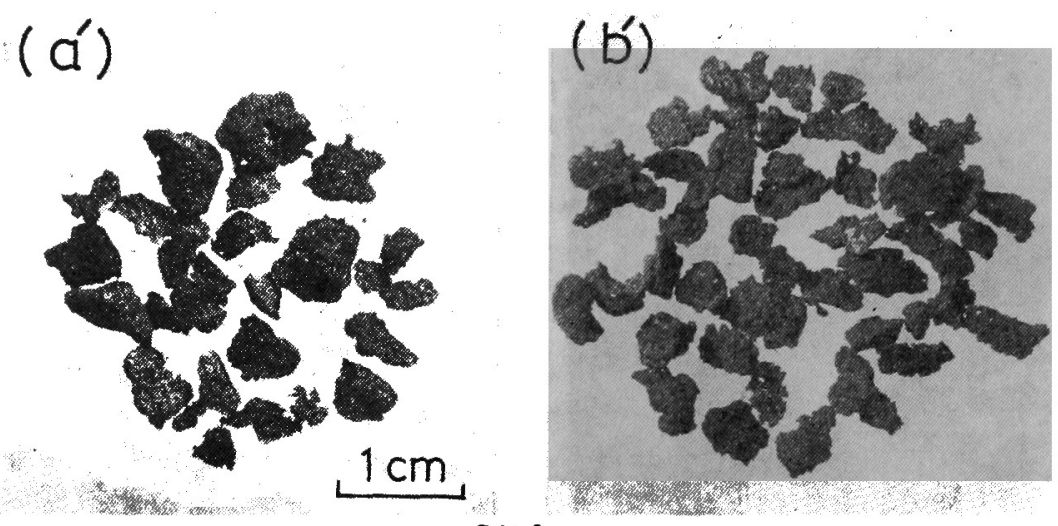

Coke fines

(a), $\left(a^{\prime}\right)$ : Sample obtained by this work $(b),\left(b^{\prime}\right)$ : Sample obtained from cooled blast furnace contents Photo. 2. Generation of macro-cracks and coke fines by alkali adsorption.

吸着率が $0.6 \%$ (第 26 次操業のマタロき裂コークスがみ られた炉内残留ュークスの第 6 層に相当するアルカリ濃 度）近傍からコークスにき裂の発生することがわかる。

Photo. 2 にBコークスのアルカリ吸着によるマクロき 裂扰よび細粒化ュークスの発生状況を実験試料（第 2 段 階における試料）と炉内試料について対比して示した.

これによるとアルカリを吸着したコークスの黒色化, マクロき裂の発生状況ならびに細粒化ュークスの外観 は, 両者ともよく似ている.またマクロき裂の特徵は, いずれの場合もコークス塊の径方向に直線的に入る形態 のものと，塊の表面に沿つて同心円状に入る形態のもの に大別でき，細粒化コークスはいずれも偏平状に破砕し た形状のものが多い.

Photo. 3 にアルカリの吸着によつて劣化したコークス からマクロき裂発生コークスを除いた試料と炉内残留コ ークスの第 9 層の黒色コークス(アルカリを多量付着し ている）の気孔壁部のミクロき裂の発生状沅を対比して 示した. このよらに両者のミクロき裂の発生状況が類似 していること,さらに別報15)でのべたようにガス化反応 のみでは気孔壁内にミク口き裂が発生しないといら実験
的事実からみて, Photo. 3 に示したミクロき裂はアルカ リ吸着によつて生じたものであり、このミクロき裂が内 部へと生長してマクロき裂につながるものと思われる。

このようにアルカリの吸着によつて, 確かに試験高炉 内でみられたようなマクロき裂と細粒化コークスが再現 できた。

これらからアルカリの吸着はコークスのき裂発生の少 なくとも一つの要因であると思われる，しかし，A， B コークスの同一アルカリ吸着率に拈けるき裂発生率をみ ると，Aュークスの方が逆に高くなつている. したがつ て，アルカリの吸着によるコークスの劣化のみによつて は, 第 26 次操業に牧ける A， B ュークスの明り上うな 差6)を説明できないことになる.

$3 \cdot 2 \cdot 2$ アルカリ吸着によるコークスの劣化に及ぼす $\mathrm{PCO}_{2}$ の影響

第 3 段階までの間に $N_{2}$ 雲囲気ではき裂が発生して も，他の条件を同じにして $\mathrm{CO}_{2}$ ガスを添加するとき裂 が全く発生しなくなる現象がみとめられ， $\mathrm{CO}_{2}$ ガスによ るアルカリ分王の低下が推察された。 そこで $\mathrm{CO}_{2}$ ガス のこの効果が現われる限界分圧，それに及ぼすュークス 


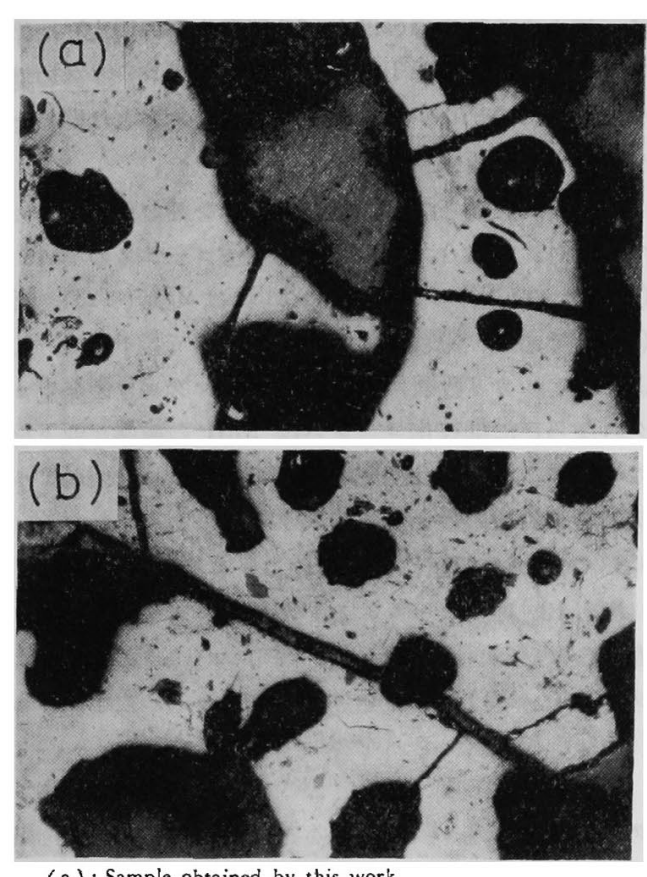

(a) : Sample obtained by this work

(b) : Sample obtained from cooled blast furnace contents

Photo. 3. Optical micrographs of micro-cracks around pores caused by alkali adsorption.

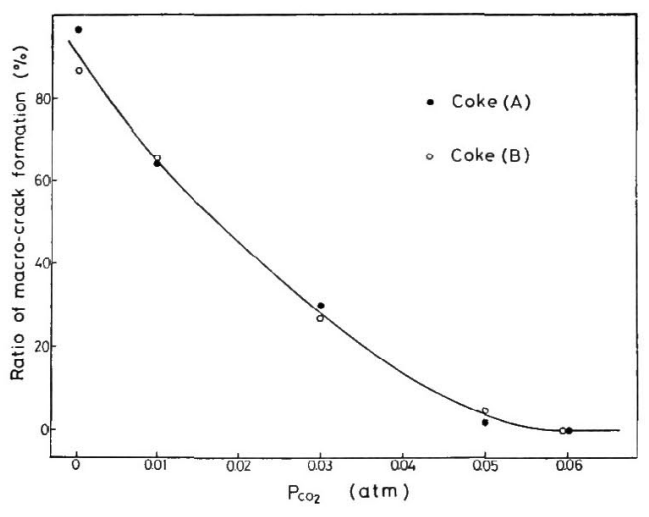

Fig. 8. Relation between $P_{\mathrm{CO}_{2}}$ and ratio of macrocrack formation at $1000^{\circ} \mathrm{C}$.

の反応性（コークス種による）の影響についての調査を 行なつた.

Fig. 8 は $1000^{\circ} \mathrm{C}, \mathrm{N}_{2}$ 䨌团気でマクロき裂の発生す る条件を出発点とし， $\mathrm{CO}_{2}$ ガスを添加していつたとき の $\mathrm{CO}_{2}$ 濃度とマクロき裂発生率の関係を示したもので ある.この図から明らかなよらに，マクロき裂発生率は $\mathrm{CO}_{2}$ ガスの添加によつて低下し， $P_{\mathrm{CO}_{2}}$ が 0.05 0.06 atm 以上になるとき裂が全く発生しなくなる.このこと
から $\mathrm{CO}_{2}$ ガスはアルカリ金属蒸気と反応して，これを 酸化し，その分圧を低下させ，アルカリ吸着を抑制する 作用を持っものと思われる.

また，A， Bコークスのマクロき裂発生率を比較する 之両者に差がみられない。したがつて Fig. 7 でみられ る $\mathrm{A}, \mathrm{B}$ コークスのき裂発生率の差が $\mathrm{CO}_{2}$ ガスの添加 によつてなくなるといらことになり，そこにA，Bコー クスの反応性の差が現われているとも考学られる。

しかしいずれにしてもA，Bュークスの反応性の違い がアルカリ吸着に上るき裂発生率の差を大きく逆転させ るとは考えられない。

3.2 .3 アルカリ吸着に上る劣化コークスの強度特性 について

ここでは, アルカリ吸着によつて生じたマクロき裂発 生コークス，細粒化コークス，およびこれらを含めた実 験後の混合試料についての強度特性を調べた，なお，強 度試験法としては炉内残留コークス中の細粒化コークス の MSI がとくに顕著に低かつたことから，マイクロ・ ストレングス試䥒法を採用した。

Fig. 9 にアルカリ吸着によつて劣化したコークスの混 合試料（マクロき裂発生コークスと細粒化コークスを含 む）のき裂発生率と MSI との関係を示した．これによ るとき裂発生率の增大に伴つて MSI は低下し, き裂発 生率はとくに MSI $(+28)$ とよく対応する.

Fig. 10, Fig. 11 にアルカリ吸着によつて劣化したコ ークスからマクロき裂発生コークスと細粒化コークスの

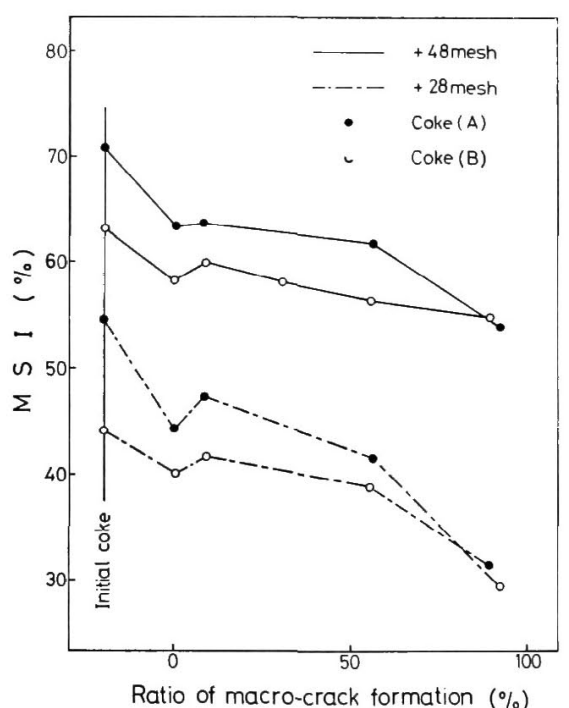

Fig. 9. Relation between ratio of macro-crack formation and MSI. 


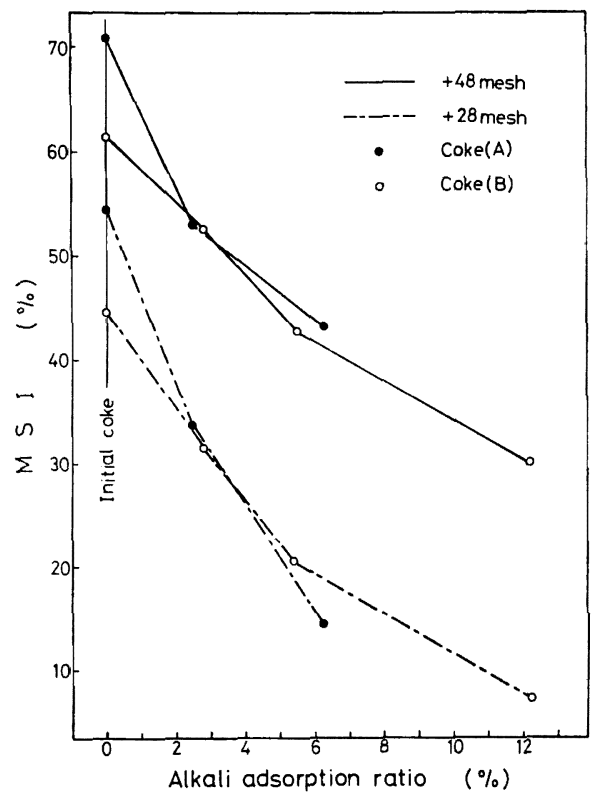

Fig. 10. Relation between alkali adsorption ratio and MSI of macro-cracked coke.

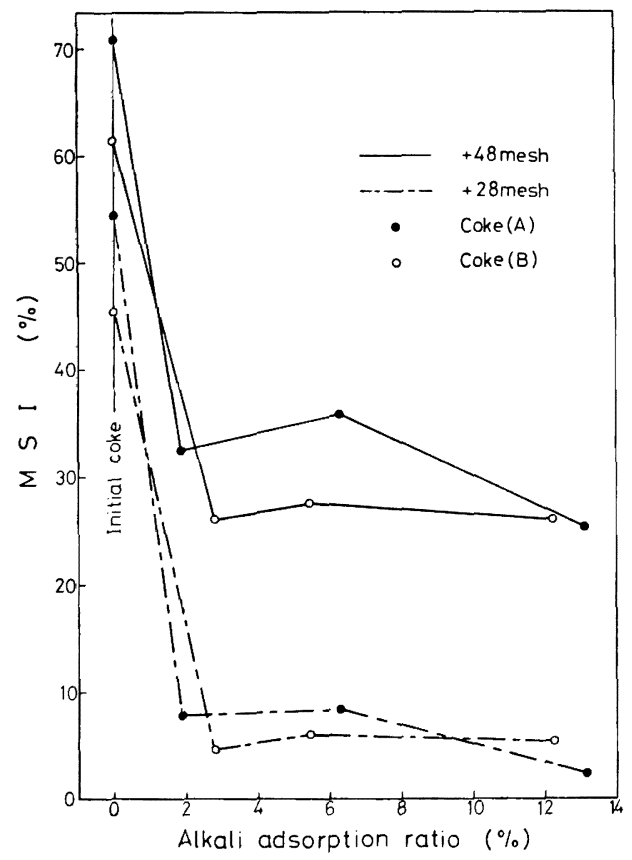

Fig. 11. Relation between alkali adsorption ratio and MSI of coke fines.

みを選び出し，それらのアルカリ吸着率と MSI との関 係を示した. これらによるとマクロき裂発生コークス
は，アルカリ吸着率の増大（き裂発生率の増大）に伴つ て MSI は急激に低下しており, 細粒化ュークスの場合 は，さらに MSI が低く，アルカリ吸着率とは関係なく 一定値を示している.

この実験試料と炉内試料の MSI を細粒化コークスに ついて対比すると，例えば炉内残留コークスの第 16 層 (アルカリ吸着率：1.85\%)の MSI は 27\%(+28)，46\% (+48)であり，実験試料のそれに比へて若干高い。この ようにアルカリ吸着によつて生じたマクロき裂発生コ一 クスならびに細粒化ュークスは MSI の極端な低下をき たすが，これは気孔壁内に発生するミク口き裂がアルカ リ吸着率の増大とともに増大するためだと思われる．

\section{3 アルカリ吸着による劣化コークスのX線回折}

Fig. 12 にBコークスのアルカリ吸着率が $1.93 \%$ の 場合のX線回折図を示した. 図の（a)はき裂未発生コ一 クス粒子，(b)はマクロき裂発生コークス粒子，さらに (c)は細粒化ュークスを示している.

これらによるとマクロき裂の発生, さらに細粒化コー クスヘとアルカリ吸着による劣化が進むに従つて, 黒鉛 のピークがブロード化し，かつその高さが小さくなる. な抗この傾向はA $\mathrm{A}$ ムスの場合についても同様である が，黒鉛のピークが相対的にBュークスに比べ若干高い のが特徽的である.

コークスは一般にアルカリを吸着し、扊分とは KAlSi$\mathrm{O}_{4}$ ，炭素質部分では黒鉛と層間化合物 $\left(\mathrm{C}_{x} \mathrm{~K}\right)$ を作り， このさい「ひずみ」発生による黒鉛ピークのプロード化 が特こると報告されている14,16,17)。

本実験試料の $\mathbf{X}$ 線回折では, アルカリ化合物として $\mathrm{KAlSiO}_{4}$ は検出されず $\mathrm{K}_{2} \mathrm{CO}_{3} \cdot 1 \frac{1}{2} \mathrm{H}_{2} \mathrm{O}$ が検出され た.これはアルカリ種として $\mathrm{KOH}$ を使用したことによ る影響かと思われる。

Fig. 12 の黒鉛ピークのプロード化は層間化合物の生 成による「ひずみ」の発生に起因すると思われ，またこ の進行とコークスの劣化程度とがよく対応していること から，アルカリ吸着によるコークスの劣化は C-K 層間 化合物が生成し，その増大に伴つて「ひずみ」が大きく なつてき裂発生にいたつたものと推察される.

このようにき裂発生原因を層間化合物の生成による 「ひずみ」の発生と考えると，「ひずみ」応力は同一吸 着率でみると, 気孔率の小さい緻密なコークスほど強く 㗢き，アルカリの効果をらけやすいと考えられる。 た，この考えは近藤らの報告18) の中でもみられ，Fig.7 のAュークス（気孔率：45.1\%) が B コークス（気孔 率: $47.4 \%$ ）にくらぺき裂発生率が高いのは，このこと と関係するものと思われる。 


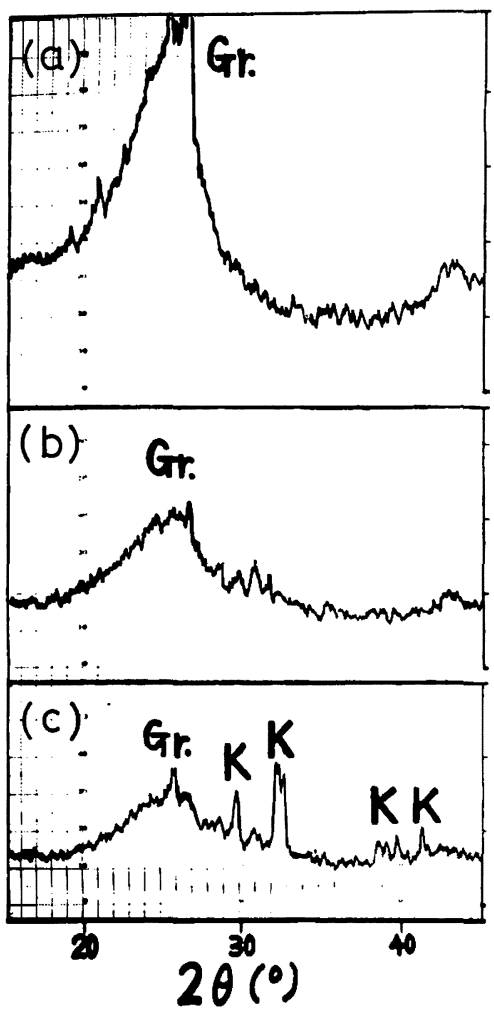

$\mathrm{Gr}:$ Graphite $\mathrm{K}: \mathrm{K}_{2} \mathrm{CO}_{3} \cdot 11 / 2 \mathrm{H}_{2} \mathrm{O}$ (a): Coke without cracks (b) : Macro-cracked coke (c): Coke fines

Fig. 12. X-ray diffraction diagram of coke after adsorption of alkali by $1.93 \mathrm{wt} \%$.

いずれにしてもアルカリ吸着による劣化一細粒化は, コークス種を選ばずおこり，少なくとも $1000^{\circ} \mathrm{C}$ 付近 という温度域に関する限りでは，コークス一般の劣化の 原因とはなりらるとしても，Bコークスの著しい劣化の 原因とは考えにくいよらに思われる.

\section{4. 総括}

アルカリ吸着によるコークスの劣化に関する基礎実験 を行なつて，これを確認し，次のような結果を得た。

（1）アルカリの吸着は，当初気孔壁内部で括こり， そこからカーボン質内部へと払散し，粒子全体としての アルカリ吸着率はコークスの初期気孔率に依存するよ5 である.

（2）アルカリはコークス種を選ぱず吸着され，その $1 \%$ 未満の吸着によつてもマクロき裂および細粒化コー クスが発生する。またそのき裂発生率はアルカリ吸着率 の増大に伴つて増大し，同一吸着率で比較すると気孔率 の小さいA ュークスが高い。
（3） $\mathrm{CO}_{2}$ ガスの添加は，マクロき裂発生率を低下 させ， $P_{\mathrm{CO}_{2}}$ が 0.05 0.06 atm 以上になるとき裂が全 く発生しなくなる. $\mathrm{CO}_{2}$ の存在によりアルカリ吸着に よるコークスの劣化がおこりにくくなると思われる．

（4）アルカリ吸着によるマクロき裂発生コークスな らびに細粒化コークスのミクロ強度は, アルカリ吸着率 の增大に伴つて，前者は急低下寸るが，後者は極端に低 いほぽ一定値をとる。

（5）アルカリを吸着したコークスは，それによる劣 化が進むに従つて，黒鉛のピークがプロード化し，かつ その高さが小さくなる.

これらの結果から判断する限りにおいては, アルカリ の吸着はコークス一般の劣化の原因とはなりらるとして も，第 $25 \cdot 26$ 次操業の $B$ コークスの著しい劣化の要因 になつたとは考えにくい.

\section{交献}

1) 下村泰人, 西川絫, 有野俊介, 片山 力, 肥田 行博, 磯山 正：鉄と鋼，62(1976)，p. 547

2 ) 小嶋鴻次郎, 西徹, 山口德二, 仲摩博至, 井 田四郎：鉄と鋼，62(1976)，p. 570

3 ) 佐々木寞太郎, 羽田野道春, 渡辺雅男, 下田輝久, 横谷勝弘，伊東孝夫，横井毅：鉄と鋼， 62 (1976)， p. 580

4 ) 館 充, 桑野芳一, 鈴木吉哉, 張 東植, 吳 平男，松崎幹康：鉄と鋼，62(1976)，p. 495

5 ) 田口整司, 小板橋寿光, 稲谷稔宏, 高田至康, 槌 谷暢男, 高橋洋光, 奥村知男, 田川義輝: 鉄之鍓, 63 (1977), A 71

6 ) $M$. TATE, et al.: Trans. ISIJ, 投稿中

7 ) 張 東植, 館 充：鉄と鋼，61 (1975), S 26

8 ) 張 東植, 鈴木吉哉, 館 充: 鉄と鋼, 61 (1975), S 366

9 ) 張 東植, 館 充: 鉄々鋼, 62(1976), S 408

10) 張 東植, 館 充：鉄々鋼, 63(1977), S 525

11) 張 東植, 館 充: 学振 54 委-1341(1975)

12) $W . K$. Lu: Alkali in Blast Furnace-State of Art, P. 2-1 (1973)

13）桘谷暢男：第 2 回鉄鋼工学セミナーテキスト, (1976)，p. 9

14）近藤幹夫，小西行雄，岡部俠児：鉄と鋼，62 (1976), S 28

15) 張 東植, 館 充: 鉄と鋼, 65(1979), p. 13

16) R. J. Hawkins, $L$. Monte, and $J \cdot J$.WAters: Ironmaking and Steelmaking (Quarterly), (1974), 3, P. 151

17) N. L. Golidshtein, et al.: Stal', (1975), 11, p. $977 \sim 981$

18）近藤幹夫，小西行雄，岡部俠肾：鉄と鋼，64 (1978), A 13 